\title{
PERLINDUNGAN KONSUMEN TRANSPORTASI OTOBUS: STUDI YURIDIS KELAYAKAN TRANSPORTASI OTOBUS DI KOTA SURAKARTA
}

\author{
Ricky Setiawan, S.H. \\ Mahasiswa Magister Ilmu Hukum UMS
}

\begin{abstract}
7 ransportation has always been an interesting thing to be researched and developed in Indonesia. In addition to supporting the economic movement, transportation management in Indonesia is relatively not well with various facts. In this study, the authors raised the theme of transport autobus which still needs many improvements. Namely to examine the object PO Mulyo Beautiful and Perum Damri in Surakarta classified as organizing transport Otobus famous in Surakarta. The author will analyze existing practices at both institutions autobus transportation service providers are using the Law No. 8 of 1999 on Consumer Protection and Law No. 22 of 2009 on Road Traffic and Public Transport.
\end{abstract}

\section{Keywords: Transport, Otobus, Consumer Protection}

\begin{abstract}
Abstrak
$T$ ransportasi selalu menjadi satu hal menarik untuk diteliti dan dikembangkan di Indonesia. Selain untuk menunjang pergerakan ekonomi, pengelolaan transportasi di Indonesia masih terbilang belum baik dengan berbagai fakta yang ada. Dalam penelitian ini, penulis mengangkat tema transportasi otobus yang masih perlu banyak pembenahan. Yaitu dengan meneliti pada obyek PO Mulyo Indah dan Perum Damri di Kota Surakarta yang tergolong sebagai penyelenggara transportasi Otobus ternama di Kota Surakarta. Penulis akan menganalisa praktek yang ada pada kedua instansi penyelenggara jasa transportasi otobus tersebut dengan menggunakan Undang-Undang Nomor 8 Tahun 1999 tentang Perlindungan Konsumen dan Undang-Undang Nomor 22 Tahun 2009 tentang Lalu Lintas dan Angkutan Umum.
\end{abstract}

Kata Kunci: Transportasi, Otobus, Perlindungan Konsumen

\section{Pendahuluan}

Indonesia merupakan negara berkembang yang masih sangat memerlukan pembenahan pada berbagai sektor pentingnya. Salah satu sektor penting dalam menunjang pembangunan ekonomi negara adalah sektor transportasi yang masih menjadi tema menarik untuk dikembangkan. Lebih detail lagi, sektor jasa transportasi yang semakin berkembang seiring bertambahnya kebutuhan masyarakat merupakan bagian integral dan strategis dalam pembangunan ekonomi masyarakat yang notabene membutuhkan efisiensi dan efektifitas ruang dan waktu. ${ }^{1}$

Jasa transpotasi memiliki pengaruh yang signifikan dalam berbagai aspek, antara lain; aspek ekonomi, sosial, dan politik. Maka dari itu, pengaruh jasa transportasi dalam pertumbuhan ekonomi di Indonesia sangatlah besar. Karena dengan jasa transportasi masyarakat dan barang akan berpindah lebih mudah dan lebih cepat dari satu wilayah ke wilayah lain.

Dalam kaitannya dengan jasa transportasi, jenis transportasi yang ada di Indonesia dapat digolongkan menjadi tiga golongan, yaitu: (1) Udara, dengan sarana pesawat dan prasarana bandara; (2) Air, dengan sarana kapal dan prasarana dermaga atau pelabuhan; (3) Darat, melalui

1 Edward K. Morlok, 2002, Pengantar Teknik dan Perencanaan Transportasi, Jakarta: Erlangga, hal. 33 
jalan raya dengan sarana bus dan prasarana terminal, dan sarana kereta api dengan prasarana stasiun melalui jalan rel. ${ }^{2}$

Saat arus perpindahan masyarakat semakin padat dan meningkat, transportasi otobus atau bus sebagai sarana transportasi dapat dijadikan sebagai salah satu alternatif yang dapat digunakan untuk menunjang hal tersebut. Bus merupakan salah satu alat transportasi umum yang memiliki kapasitas pengangkutan yang besar, sehingga lebih efisien dan hemat jika dibandingkan dengan alat transportasi lain. ${ }^{3}$

Pengaturan tentang aspek hukum transportasi sendiri terdapat di dalam Undang-Undang Nomor 22 Tahun 2009 tentang Lalu Lintas dan Angkutan Jalan. Peraturan perundang-undangan tersebut merupakan landasan normatif dilaksanakannya pengangkutan jasa transportasi bus di Indonesia yang disesuaikan dengan Pasal 3 Undang-Undang Nomor 22 Tahun 2009 tentang Lalu Lintas dan Angkutan Jalan. Selain itu, masyarakat sebagai pengguna transportasi bus harus mendapatkan perlindungan oleh hukum sebagai pengguna atau konsumen jasa transportasi bus. Hal ini sesuai dengan Undang-Undang Nomor 8 Tahun 1999 tentang Perlindungan Konsumen Pasal 1 Angka 2, dan mengenai perlindungannya terhadap konsumen didefinisikan dalam Pasal 1 Ayat 1.

Keterkaitan pengguna jasa angkutan sebagai konsumen terlihat pada Undang-Undang Nomor 22 Tahun 2009 tentang Lalu Lintas dan Angkutan Jalan Pasal 1 Angka 22 yang menyebutkan "pengguna jasa adalah perseorangan atau badan hukum yang menggunakan jasa perusahaan angkutan umum". Melalui peraturan tersebut terdapat hubungan antara konsumen dan jasa angkutan, bahwa pengguna jasa angkutan dalam hal ini dikategorikan sebagai konsumen jasa angkutan. Maka, sebagai konsumen, pengguna jasa tidak lepas dari aspek perlindungan baik dari kerugian yang mungkin diderita atau terjadi pada saat menggunakan jasa angkutan atau sedang melakukan perjalanan dengan alat transportasi yang disediakan oleh perusahaan angkutan. ${ }^{4}$

Masalah yang dikaji dalam penelitian ini adalah bagaimanakah perlindungan hukum terhadap konsumen transportasi bus di PO Mulyo Indah dan Perum Damri.

Adapun tujuan penelitian ini adalah untuk mendeskripsikan perlindungan hukum terhadap konsumen transportasi bus PO Mulyo Indah dan Perum Damri. Sedangkan manfaatnya secara global adalah melalui penelitian ini diharapkan dapat berguna untuk menjadi bahan pemikiran bagi perkembangan pengetahuan dan keilmuan mengenai hukum, khususnya di bidang hukum perlindungan konsumen dan jasa layanan transportasi bus secara umum.

\section{Metode Penelitian}

Dalam penelitian ini, penulis menggunakan metode penelitian yang dilakukan dengan pendekatan non-doktrinal yang kualitatif. ${ }^{5}$ Hal ini disebakkan di dalam penelitian ini, hukum tidak hanya dikonsepkan sebagi keseluruhan asas-asas dan kaidah yang mengatur kehidupan manusia dalam masyarakat, melainkan meliputi pula lembaga-lembaga dan proses-proses yang mewujudkan berlakunya kaidah-kaidah itu dalam masyarakat, yaitu sebagai perwujudan makna-makna simbolik dari pelaku sosial, sebagaimana termanifestasi dan tersimak dalam dan dari aksi serta interkasi antar mereka.

Dalam penelitian ini penulis menggunakan metode analisis data secara Kualitatif. Data yang diperlukan dalam penelitian ini, akan dikumpulkan melalui tiga cara, yaitu : melalui wawancara, observasi dan studi kepustakaan.

2 Ahmad Munawar, 2005, Dasar-dasar Teknik Transportasi, Jogjakarta: Betta Offset, hal. 2

3 Randy Gunawan, 2011, Skripsi Hukum, Perlindungan Hak Konsumen Pengguna Jasa Layanan Transportasi Bus Transjakarta-Busway sesuai dengan Undnag-undnag Nomor 8 Tahun 1999 Tentang Perlindungan Konsumen, Jakarta: Universitas Indonesia

4 Lanugranto Adi Nugroho, 2008, Skripsi Hukum, Konsumen dan Jasa Transportasi (Studi Terhadap Perlindungan Hukum pada Konsumen Fasilitas Publik Transportasi Darat dan Pelayanan Jasa Transportasi Perusahaan Otobus di Kabupaten Wonogiri), Surakarta: Universitas Muhammadiyah Surakarta, hal. 5

5 Soetandyo Wignjosoebroto, Silabus Metode Penelitian Hukum, Program Pascasarjana Universitas Airlangga, Surabaya: tt, hal. 1 dan 3 


\section{Hasil Penelitian Dan Pembahasan}

\section{Perlindungan Konsumen pada PO Mulyo Indah dan Perum Damri}

Pengangkutan adalah perjanjian timbal balik antara pengangkut dengan pengirim, dimana pengangkut mengikatkan diri untuk menyelenggarakan pengangkutan barang dan/atau orang dari satu tempat ke tempat tujuan tertentu dengan selamat, sedangkan pengirim mengikatkan diri untuk membayar uang angkutan. ${ }^{6}$

PO Mulyo Indah berdiri pada tahun 1976 di Kota Surakarta. Jurusan angkut untuk PO Mulyo Indah terdapat lima jurusan angkut yang meliputi luar wilayah Kota Surakarta dimana PO Mulyo Indah merupakan bis dengan jurusan Antar Kota Antar Provinsi (AKAP) dan jurusan Antar Kota Dalam Provinsi (AKDP). Kelima jurusan yang dikelola oleh PO Mulyo Indah adalah Surakarta-Semarang, Surakarta-Bogor, Surakarta-Jakarta, Yogyakarta-Bogor dan YogyakartaJakarta.

Perum Damri Kota Surakarta didirikan pada tahun 1983 di Kota Surakarta. Perum Damri memiliki tiga trayek yang hingga saat ini masih digunakan untuk jurusan armadanya, yaitu Terminal Palur-Bandara Adi Sumarmo, Bandara Adi Sumarmo-Terminal Tirtonadi dan Surakarta-Yogyakarta.

Penelitian ini berfokus pada tiga point besar, yaitu; standar pelayanan angkutan, pengelolaan alat angkut dan manajemen pengemudi. Kesemuanya dikaitkan dengan asas perlindungan konsumen yang harus diperhatikan oleh perusahaan jasa transportasi yang dalam penelitian ini terwakilkan melalui P. O Mulyo Indan dan Perum Damri.

\section{Standar Pelayanan Minimal Angkutan}

Standar pelayanan minimal angkutan yang harus dipenuhi oleh kedua perusahaan transportasi otobus P. O. Mulyo Indan dan Perum Damri telah diatur dalam Peraturan Menteri Perhubungan Nomor 98 Tahun 2013 tentang Standar Pelayanan Minimal Angkutan Orang dengan Kendaraan Bermotor Umum dalam Trayek. Adapun pemenuhan standarisasi alat angkut dan syarat pengemudi disesuaikan dengan apa yang telah diatur dalam Undang-Undang Nomor 22 Tahun 2009 tentang Lalu Lintas dan Angkutan Jalan.

Sesuai Pasal 3 Ayat (1) Undang-Undang Nomor 22 Tahun 2009 tentang Lalu Lintas dan Angkutan Jalan bahwa tujuan dari pengangkutan adalah "terwujudnya lalu lintas dan angkutan jalan yang aman, selamat, tertib, lancar dan terpadu dengan moda angkutan lain untuk mendorong perekonomian nasional, memajukan kesejahteraan umum, memperkukuh persatuan dan kesatuan bangsa serta mampu menjunjung tinggi martabat bangsa."

Pada Pasal 2 Ayat (2) Peraturan Menteri Perhubungan Nomor 98 Tahun 2013 tentang Standar Pelayanan Minimal Angkutan Orang Dengan Kendaraan Bermotor Umum dalam Trayek yang meyebutkan "Standar pelayanan minimal sebagaimana dimaksud pada Ayat (1) meliputi: a. Keamanan; b. Keselamatan; c. Kenyamanan; d. Keterjangkauan; e. Kesetaraan; dan f. Keteraturan."

Peraturan Menteri Perhubungan Nomor 10 Tahun 2012 tentang Standar Pelayanan Minimal Angkutan Masal Berbasis Jalan juga menjelaskan tentang standar pelayanan minimal yang diatur dalam Pasal 3 Ayat (3) yang menyebutkan bahwa; "Standar pelayanan minimal sebagaimana dimaksud pada Ayat (1) meliputi: a. Jenis pelayanan; dan b. Mutu pelayanan." Ayat (4) juga mengokohkan bahwa; " jenis pelayanan sebagaimana dimaksud pada Ayat (3) huruf a meliputi: a. Keamanan; b. Keselamatan; c. Kenyamanan; d. Keterjangkauan; e. Kesetaraan; dan f. Keteraturan." Beberapa peraturan tersebut berkaitan dengan hak-hak penumpang yang merupakan konsumen pengguna jasa transportasi.

Jika disinggungkan dengan Pasal 4 huruf a Undang-Undang Nomor 8 Tahun 1999 tentang Perlindungan Konsumen, PO Mulyo Indah belum memenuhi standar minimal pelayanan

6 H.M.N. Purwosutjipto, 1987, Pengertian Pokok Hukum Dagang Indonesia 3 Hukum Pengangkutan, Jakarta: Djambatan, hal 2 
angkutan karena belum memenuhi; (1) Kategori keamanan berupa tiket penumpang dan lampu kendaraan, (2) Kategori keselamatan berupa peralatan keselamatan dan fasilitas kesehatan, (3) Kategori kenyamanan berupa kapasitas angkut, fasilitas pengatur suhu ruangan, fasilitas kebersihan dan luas lantai untuk berdiri perorang, dan (4) Kategori keteraturan berupa informasi pelayanan. Sedangkan untuk kategori keterjangkauan dan kategori kesetaraan, PO Mulyo Indah telah memberikan pelayanan sesuai dengan Peraturan Menteri Perhubungan Nomor 10 Tahun 2012 tentang Standar Pelayanan Minimal Angkutan Masal Berbasis Jalan.

Begitu pula dengan Perum Damri belum memenuhi standar minimal pelayanan angkutan karena belum memenuhi; (1) Kategori keselamatan berupa peralatan keselamatan, (2) Kategori kenyamanan berupa kapasitas angkut, fasilitas kebersihan dan luas lantai untuk berdiri perorang, (3) Kategori kesetaraan berupa ruang penyimpanan kursi roda. Sementara itu untuk kategori keamanan, kategori keterjangkauan dan keteraturan, Perum Damri telah memberikan pelayanan sesuai dengan Peraturan Menteri Perhubungan Nomor 10 Tahun 2012 tentang Standar Pelayanan Minimal Angkutan Masal Berbasis Jalan.

\section{Pengelolaan Alat Angkut}

Menurut Pasal 48 Undang-Undang Nomor 22 Tahun 2009 tentang Lalu Lintas dan Angkutan Jalan menjelaskan bahwa pemenuhan syarat teknis dan laik jalan antara lain adalah:

a. Setiap kendaraan bermotor yang dioperasikan di jalan harus memenuhi persyaratan teknis dan laik jalan.

b. Persyaratan teknis sebagaimana dimaksud pada Ayat (1) terdiri atas; susunan, perlengkapan, ukuran, karoseri, rancangan teknis kendaraan sesuai dengan peruntukannya, pemuatan, penggunaan, penggandengan kendaraan bermotor dan/ atau penempelan kendaraan bermotor.

c. Persyaratan laik jalan sebagaimana dimaksud pada Ayat (1) ditentukan oleh kinerja minimal Kendaraan Bermotor yang diukur sekurang-kurangnya terdiri atas; emisi gas buang, kebisingan suara, efisiensi sistem rem utama, efisiensi sistem rem parkir, kincup roda depan, suara klakson, daya pancar dan arah sinar lampu utama, radius putar, akurasi alat penunjuk kecepatan, kesesuaian kinerja roda dan kondisi ban dan kesesuaian daya mesin penggerak terhadap berat Kendaraan.

d. Ketentuan lebih lanjut mengenai persyaratan teknis dan laik jalan sebagaimana dimaksud pada Ayat (2) dan Ayat (3) diatur dengan peraturan pemerintah. Kesimpulannya mengatakan berdasarkan penelitian yang dilakukan pada PO Mulyo Indah dan Perum Damri kedua perusahaan otobus tersebut telah memenuhi syarat teknis dan layak jalan pada tiap armadanya.

Selanjutnya, Undang-Undang Nomor 22 Tahun 2009 tentang Lalu Lintas dan Angkutan Jalan Pasal 49 Ayat (1) menjelaskan "Kendaraan Bermotor, kereta gandengan, dan kereta tempelan yang diimpor, dibuat dan/atau dirakit di dalam negeri yang akan dioperasikan di Jalan wajib dilakukan pengujian." Ayat (2) menyebutkan "Pengujian sebagaimana dimaksud pada Ayat (1) meliputi: a. uji tipe; dan b. uji berkala." Pasal 50 Ayat (2) menyebutkan sebagai berikut : Uji tipe sebagaimana dimaksud pada Ayat (1) terdiri atas: a. pengujian fisik untuk pemenuhan persyaratan teknis dan laik jalan yang dilakukan terhadap landasan Kendaraan Bermotor dan Kendaraan Bermotor dalam keadaan lengkap; dan b. penelitian rancang bangun dan rekayasa Kendaraan Bermotor yang dilakukan terhadap rumah-rumah, bak muatan, kereta gandengan, kereta tempelan, dan Kendaraan Bermotor yang dimodifikasi tipenya. Pasal 53 Ayat (2) menyebutkan sebagai berikut : Pengujian berkala sebagaimana dimaksud pada Ayat (1) meliputi kegiatan: a. pemeriksaan dan pengujian fisik Kendaraan Bermotor; dan b. pengesahan hasil uji. 
Berdasarkan penelitian yang telah dilakukan penulis pada PO Mulyo Indah dan Perum Damri telah melalui tahap pengujian yang dilakukan oleh Pemerintah Kota Surakarta melalui Dinas Perhubungan Komunikasi dan Informatika Kota Surakarta selama enam bulan sekali.

Kendaraan bermotor yang dioperasikan di jalan wajib memenuhi dengan perlengkapan kendaraan bermotor sesuai dengn Pasal 57 Ayat (1) Undang-Undang Nomor 22 Tahun 2009 tentang Lalu Lintas dan Angkutan Jalan yang menyebutkan "setiap kendaraan bermotor yang dioperasikan di jalan wajib dilengkapi dengan perlengkapan kendaraan bermotor." Kendaraan bermotor beroda empat seperti kendaraan bis yang merupakan alat angkutan umum sekurang-kurangnya harus terdapat perlengkapan kendaraan bermotor yang disebutkan pada Pasal 57 Ayat (3) yaitu : Perlengkapan sebagaimana dimaksud pada Ayat (1) bagi Kendaraan Bermotor beroda empat atau lebih sekurang-kurangnya terdiri atas: sabuk keselamatan; ban cadangan; segitiga pengaman; dongkrak; pembuka roda; helm dan rompi pemantul cahaya bagi Pengemudi Kendaraan Bermotor beroda empat atau lebih yang tidak memiliki rumahrumah; dan peralatan pertolongan pertama pada Kecelakaan Lalu Lintas. PO Mulyo Indah belum melengkapi peralatan angkut pada tiap armada yaitu pada peralatan pertolongan pertama pada kecelakaan lalu lintas (P3K).

\section{Manajemen Pengemudi}

Pada Pasal 77 Ayat (1) menjelaskan "setiap orang yang mengemudikan kendaraan bermotor di jalan wajib memiliki surat izin mengemudi sesuai dengan jenis kendaraan bermotor yang dikemudikan." Dan Ayat (2) menyebutkan "surat izin mengemudi sebagaimana dimaksud pada Ayat (1) terdiri atas 2 (dua) jenis: a. surat izin mengemudi kendaraan bermotor perseorangan; dan b. surat izin mengemudi kendaraan bermotor umum." Pengemudi armada bis wajib memiliki surat izin mengemudi golongan B I yang berlaku untuk mengemudikan mobil penumpang dan barang perseorangan dengan jumlah berat yang diperbolehkan lebih dari 3.500 (tiga ribu lima ratus) kilogram, sesuai dengan Pasal 80 hurufb Undang-Undang Nomor 22 Tahun 2009 tentang Lalu Lintas dan Angkutan Jalan yang menyebutkan "surat izin mengemudi B I berlaku untuk mengemudikan mobil penumpang dan barang perseorangan dengan jumlah berat yang diperbolehkan lebih dari 3.500 (tiga ribu lima ratus) kilogram." Pada PO Mulyo Indah dan Perum Damri telah memenuhi persyaratan untuk tiap pengemudi armada bis rata-rata pengemudi yang dipekerjakan berumur di atas 25 (dua puluh lima) tahun dan sudah memiliki pengalaman serta surat izin mengemudi (SIM) golongan B I.

Waktu kerja tiap pengemudi armada bis paling lama 8 (delapan) jam sehari atau 12 (dua belas) jam sehari termasuk waktu istirahat selama 1 (satu jam) sesuai dengan Undang-Undang Nomor 22 Tahun 2009 tentang Lalu Lintas dan Angkutan Jalan Pasal 90 yang menyebutkan : (1) Setiap Perusahaan Angkutan Umum wajib mematuhi dan memberlakukan ketentuan mengenai waktu kerja, waktu istirahat, dan pergantian Pengemudi Kendaraan Bermotor Umum sesuai dengan ketentuan peraturan perundang-undangan. (2) Waktu kerja bagi Pengemudi Kendaraan Bermotor Umum sebagaimana dimaksud pada Ayat (1) paling lama 8 (delapan) jam sehari. (3) Pengemudi Kendaraan Bermotor Umum setelah mengemudikan Kendaraan selama 4 (empat) jam berturut-turut wajib beristirahat paling singkat setengah jam. (4) Dalam hal tertentu Pengemudi dapat dipekerjakan paling lama 12 (dua belas) jam sehari termasuk waktu istirahat selama 1 (satu) jam. Berdasarkan hasil penelitian, PO Mulyo Indah dan Perum Damri sudah memenuhi untuk pemberian waktu kerja kepada pengemudi, yaitu pada PO Mulyo Indah memiliki waktu kerja maksimal 12 (dua Belas) jam, sedangkan untuk Perum Damri memiliki waktu kerja maksimal 10 (sepuluh) jam.

\section{Penutup} lain:

Sebagai penutup, penulis menyimpulkan beberapa hal sebagai simpulan dan saran, antara 
Pertama, konsumen transportasi bus PO Mulyo Indah dan Perum Damri terlindungi dalam hal keterjangkauan, pemenuhan syarat teknis dan laik jalan, pengujian kendaraan bermotor dan pengemudi armada bus sesuai dengan Undang-Undang yang telah dijelaskan dalam penelitian ini.

Kedua, konsumen transportasi bus PO Mulyo Indah dan Perum Damri belum terlindungi dalam keamanan, keselamatan, kenyamanan, kesetaraan dan keteraturan, karena tidak sesuai dengan berbagai peraturan dan undang-undang yang telah dikaji dalam penelitian ini.

Ketiga, saran yang bisa dikerucutkan adalah optimalisasi pengadaan sarana dan prasarana bus dari pihak pemerintah Kota Surakarta, optimalisasi pelayanan jasa dari pihak penyelenggara angkutan jasa, dan serta kedewasaan dan kewaspadaan para pengguna jasa angkutan umum, khususnya bus, demi terpenuhinya hak-hak mereka.

\section{Daftar Pustaka}

Gunawan, Randy. 2011, Skripsi Hukum, Perlindungan Hak Konsumen Pengguna Jasa Layanan Transportasi Bus Transjakarta-Busway sesuai dengan Undnag-undnag Nomor 8 Tahun 1999 Tentang Perlindungan Konsumen, Jakarta: Universitas Indonesia.

Morlok, Edward K. 2002, Pengantar Teknik dan Perencanaan Transportasi, Jakarta: Erlangga. Munawar, Ahmad. 2005, Dasar-dasar Teknik Transportasi, Jogjakarta: Betta Offset.

Nugroho, Lanugranto Adi. 2008, Skripsi Hukum, Konsumen dan Jasa Transportasi (Studi Terhadap Perlindungan Hukum pada Konsumen Fasilitas Publik Transportasi Darat dan Pelayanan Jasa Transportasi Perusahaan Otobus di Kabupaten Wonogiri), Surakarta: Universitas Muhammadiyah Surakarta.

Purwosutjipto, H.M.N. 1987, Pengertian Pokok Hukum Dagang Indonesia 3 Hukum Pengangkutan, Jakarta: Djambatan

Wignjosoebroto, Soetandyo. Silabus Metode Penelitian Hukum, Program Pascasarjana Universitas Airlangga, Surabaya: tt.

Undang-Undang Nomor 8 Tahun 1999 tentang Perlindungan Konsumen.

Undang-Undang Nomor 22 Tahun 2009 tentang Lalu Lintas dan Angkutan Jalan.

Peraturan Menteri Perhubungan Nomor 10 Tahun 2012 tentang Standar Pelayanan Minimal Angkutan Massal Berbasis Jalan.

Peraturan Menteri Perhubungan Nomor 98 Tahun 2013 tentang Standar Pelayanan Minimal Angkutan Orang dengan Kendaraan Bermotor Umum dalam Trayek.

Peraturan Daerah Nomor 1 Tahun 2013 tentang Penyelenggaraan Perhubungan. 